\title{
Aesthetics in Five Annang Folksongs: An Oral Literary Approach
}

\author{
Friday Akpan Okon ${ }^{1^{*}}$ Inimfon Dick Udoinyang ${ }^{2}$ \\ 1. Department of English, University of Uyo, Uyo, Nigeria.
}

2. Dept. of Curriculum Studies, Planning and Educational Management, University of Uyo, Uyo,. Nigeria.

\author{
*fridayokon@uniuyo.edu.ng
}

\begin{abstract}
Oral literature is an embodiment of various stylistic, archetypal and aesthetic elements. This paper shall attempt to examine and analyse aesthetics in five selected Annang folksongs. These carefully selected folksongs which cover different aspects of Annang culture are studied not only to unravel the incidents behind or the messages they contain but also to appreciate the aesthetic qualities of these songs through a study of the style of rendition. These folksongs were recorded and preserved by the researcher through verbal communication with the elders in selected Annang communities. Repetition, rhythm, alliteration, assonance, and other figures of speech as aesthetic elements are examined in this work to underscore how they enhance the beauty of the songs. This research work is of the view that Annang folksongs are legitimate manifestations of oral literature in action. The study concludes that there is need to study not just the thematic contents of Annang folksongs but also the form and style which constitute the aesthetics in Annang orature.
\end{abstract}

Keywords: Aesthetics, Annang, folksongs, orature.

DOI: $10.7176 /$ JLLL/78-07

Publication date: April $30^{\text {th }} 2021$

\section{Introduction}

Oral literature forms a generally more fundamental component of culture, but operates in many ways as one might expect literature to do. It is understood to be part or all of the lore and media with which a society conducts profound and common cultural affairs among its members, orally. In this sense, oral lore is an ancient practice and concept natural to the earliest stories, communications and transmissions of bodies of knowledge and culture in verbal form near the dawn of language-based human societies, and, oral literature thus understood, was putatively recognized in times prior to recognitions of history in non-oral media. Oral literature is a term generally applied to spoken literary traditions such as folktales, musical theatre, proverbs, riddles, life histories, plays, epic poems and historical recitations (Finnegan 1996; Onuekwusi 2001). Unlike written literary texts, oral literature is conveyed or passed down to future generations by word of mouth, typically through memorization and recitation (Finnegan 1996).

Annang oral literature is an accumulation of the knowledge and experiences of Annang people over the ages. It consists of their folk stories, war stories, and many other stories which are sometimes sung or recited to depict the ways of life of Annang people. The songs are always rendered in an elevated style, as is common with all authentic poetry. Annang oral poetry in this sense is an embodiment of the wisdom of the ancient people which mirrors the accumulated experiences of the Annang people in their traditional community.

By aesthetics here, we mean the concern with the creation and appreciation of beauty; the deployment of all the resources of language and form to make a conceptualized idea perceptible to an audience (Angmor 1993:112). It is the creation of beauty out of the ugly details of this life. The reason for undertaking this analysis of the aesthetics in Annang folksongs is that despite the popularity and the morality of these folksongs and their wide acceptance over the years, little or nothing has been done to analyse their aesthetics or literary qualities. Therefore, in view of the foregoing, this research is designed to fill this lacuna by taking up the study.

\subsection{A Brief History of Annang People}

The history of Annang people of South-South Nigeria could be traced to their origins from Bantu warriors and Zulu hunters in Central Africa. Udondata (2011: v) is of the view that their migration from the Central African forests took the Annang people to the region of the Cameroons in the $3^{\text {rd }}$ Century $\mathrm{BC}$, and they soon crossed over to settle in Eket and from there spread out to their present locations. E. U. Udoh (1983:3) asserts that the Annang are one of the aboriginal peoples that settled earlier than most other ethnic groups in the South-South coastal areas of present day Nigeria. Linguistically, Imelda Udoh (1998) is of the view that the Annang share close affinities with their Ibibio and Efik neighbours with whom her language forms a cluster of mutually intelligible languages; and together, they belong to the lower Cross group of languages which is traced to the larger NigerCongo language family (see also Greenberg 1963; Essien 1990; Williamson 1989 and Connell 1994). Presently, the Annang people are spread among eight Local Government Areas in Akwa Ibom State, namely: Abak, Essien Udim, Etim Ekpo, Ika, Ikot Ekpene, Obot Akara, Oruk Anam and Ukanafun. Annang people are identified by 
their homogeneity in culture, language and central lineage. In a nutshell, the word "Annang" refers to both the nation and the language which the inhabitants of that nation speak.

The Annang people are a proud people characterized by their qualities of frankness, friendliness and honesty. They value the ability to speak well. They have exceptional and excellent ability in using proverbs, idioms or aphorisms in expressing themselves, which is a highly desirable ability, especially among the elders. Annang people are great farmers, scholars, professionals, artisans and traders. Annang craftsmanship is unsurpassed especially in the area of raffia production and wood carving, for which their traditional headquarters Ikot Ekpene is well-known for, all over the world.

\subsection{Annang Oral Literature}

Annang land is replete with a vibrant oral literary tradition (Udondata, 2011). Oral compositions in Annang land are primarily valued as sources of entertainment, information, education and character (re)formation. According to Udondata (2011:3):

The moonlit night provided a veritable forum for members of the family to converge at the "Afe" (the circular space within the compound, or in some cases, an open thatched building without walls, used as a meeting place) for story telling sessions. At this point, friends and neighbours also formed part of such gatherings to listen to stories of many kinds. The old men told stories on war exploits of the tribe and natural disasters, (e.g. famine, diseases, etc.) Stories were told on the year a swarm of grasshoppers arrived from distant land to destroy crops.... Stories were told concerning various animals depicting bravery, courage, cunning and wisdom. Animals such as the lion, the tortoise, the hare, the monkey, the snail and various fishes featured in the story sessions. The story session not only provided entertainment and information but transmitted knowledge and desirable skills from one generation to another. Children always looked forward to such sessions where they learnt new songs, proverbs, riddles and jokes. From these stories, children learnt, to appreciate good qualities and detest bad habits.

Therefore, the oral literature of the Annang people is a reflection of their rich oratorical and philosophical culture. This unique culture is made manifest in several forms of which songs form a significant corpus.

\subsection{The Concept of Aesthetics in Literature}

The word "aesthetics" originated from the Latin word "aestheticus" and from the Greek word "aestheticos" which denotes sense of perception. In essence, aesthetics is a philosophy that is concerned with notions of beauty and appreciation. It may be considered as the study of beauty.

The concept of aesthetics in literature can be explained by drawing analogies from philosophy of the visual arts and dance. Philosophically, art is known to be a creativity which has its value in its aesthetics through performance. This can be further enunciated through the ideas that a work of art is expressive as well as being comprised of organized elements. A work of art is intelligible when it is expressive; any progress aesthetic experience makes is towards a more refined and sensitive taste which renders us more amiable and docile to the aesthetic object. More importantly, one has aesthetic experience when one finds oneself in a state of rapture or delight as one stands before a good work of art. What this means is that there is that tendency for one who has been encompassed by uncertainties to be enlivened at the sight of a good work of art (Akpan and Etuk 1990).

The deepest part of it all is the communal harmony, unity and the continual observances of traditions, customs and values which aesthetic delight generates. All of these are embedded in Annang folksongs, a selection of which constitute the focus of this paper.

$\begin{array}{ll}2 \quad \text { Analysis of Selected Annang Folksongs } \\ \begin{array}{ll}\text { Song \#1: } \\ \text { Original }\end{array} & \text { Gloss } \\ \text { Cantor: Ekpe Ikod } & \text { Leopard of the Bush } \\ \text { Chorus: Mme kpañ kpañ inehe } & \text { Mme kpang kpang inehe } \\ \text { Cantor: Àkákà úkēē? } & \text { Where did you go to? } \\ \text { Chorus: Mme kpañ kpañ inehe } & \text { Mme kpang kpang inehe } \\ \text { Cantor: Nkákà ikod } & \text { I went to the forest } \\ \text { Chorus: Mme kpañ kpañ inehe } & \text { Mme kpang kpang inehe } \\ \text { Cantor: Àgwód ifañ? } & \text { How many game did you kill? }\end{array}$


Chorus: Mme kpañ kpañ inehe

Cantor: Ngwòd ìbà

Chorus: Mme kpañ kpañ inehe

Cantor: Àláánno keed

Chorus: Mme kpañ kpañ inehe

Cantor: Àláád keed

Chorus: Mme kpañ kpañ inehe

Cantor: Àkpédé Ikút

Chorus: Mme kpañ kpañ inehe

Cantor: Ikpí ínnoho

Chorus: Mme kpañ kpañ inehe

Cantor: Tighiritik!

Chorus: Mme kpañ kpañ inehe

Cantor: Toghorotok!

Chorus: Mme kpañ kpañ inehe
Mme kpang kpang inehe

I killed two

Mme kpang kpang inehe

You shall give me one

Mme kpang kpang inehe

(you) take one

Mme kpang kpang inehe

If it was tortoise

Mme kpang kpang inehe

He will not have given me

Mme kpang kpang inehe

Tighiritik!

Mme kpang kpang inehe

Toghorotok!

Mme kpang kpang inehe

\section{Analysis of the Folksongs}

Song \# 1 above is sung in the call-response format, and it was originally sung as part of a folktale. The dramatic folksong revolves around the dialogue between two friends, a hunter (represented here as a leopard, the chief of hunters) and his friend.

\section{Aesthetic Elements}

In aesthetic terms, the singer makes good use of repetition, rhyme, rhythm, rhetorical question device, and ideophone as major stylistic features in the song. A few examples are given below:

\section{The Use of Repetition}

Most African folksongs can never be seen to be complete without repetition or refrain. It is a major stylistic element in most African folksongs which enhance the musicality and rhythmic quality of songs. In this folksong, "mmè kpáñ kpáñ inehe" is repeated as a substitute for actual drum beats (otherwise known as "verbal drumming" ("Iwiid inua") by the people during rendition, for musicality and beauty. This is an aspect of improvisation, and is also an element of ideophone which we shall later examine in greater detail. It must be said that this song is an exercise in repetition because nearly every line of the song is repeated to some extent, in the process of the call and response.

\section{The Use of Rhyme}

There is rhyme in the word "Ekpe Ikod", in the call, and "“Nkékà Ikod" in the response. Other such rhyme patterns occur in the words "àkékà úkéé?" and "Ñkékà Iköd", "àláánnö kèèd" and "àláád kèèd", as well as “Tighiritik!" which rhymes with "Tóghórótók!" This rhyming pattern accentuates the rhythm and musicality of the song thereby enhancing its beauty and melody.

\section{The Use of Rhythm}

Rhythm refers to the movement in space and in time as a result of the rising and falling pitch. The voice of the singer rises and falls in a sequence that forms regular beats, the result of which completes the musicality of the song.

\section{The Use of the Rhetorical Question Device}

There are also the use of rhetorical questions and imperatives which contribute to the rhythm and aesthetic quality of the folksong. For instance, "àkéká úké?", “àgwód ifañ?" are questions that demand answers from "Ekpe iksd" the hunter, thereby maintaining the regular flow of not only the dialogue, but also the rhythm of the call-response mode in its entirety.

\section{The Use of Ideophones}

An ideophone is a sound device which is peculiar to African orature in which the sound produced suggests its own meaning. Ideophones used in this folksong include the refrain "Mmè kpáñ kpáñ inéhé", "tighiritik", and "tóghórótók". "Mme kpáñ kpáñ inéhé" is used as a space-filler as well as an ideophone that imitates the deep sound of big drums which suggest the male principle which quests after conquest as represented by the hunter in this context; while "tighiritik" and "tóghórótók" imitate the sound of two small sister drums beaten one after the other, each being a response to the other. These small drums suggest the female principle which can never be 
ignored in traditional life. Used in this folksong, they suggest a happy state of the mind and a lightness of spirit of the hunter (Ekpè Ikod), for being fortunate in his hunting expedition for the day, as well as his friend for having received one game from his friend, the hunter. These sounds also constitute an aspect of the musicality, melody and beauty of the song.

\author{
Song \#2 \\ Refrain: Kòp idém ádiá áfàñ dēē oo! (2x) \\ Cantor: Afo'bok atike anye'te urod \\ Cantor: Afo'bok ikpaan anye'te mbaad \\ Cantor: Afo'bok úkpátrok anye'te úkpá éféd! \\ Cantor: Nkoñ áfèrè k'ikot ebe ijémmé \\ Cantor: Àtidòt k'ikot èbé ijémmé \\ Cantor: Àtáàmà k'ikst èbé ijemme \\ Cantor: Àkpáimo idià-nkoñ k’ikot èbé ijémmé.
}

\title{
Gloss
}

Refrain: Look at the one who eats afang soup oo! $(2 \mathrm{x})$

Cantor: You cook okro soup, he complains of sliminess

Cantor: You cook melon soup, he complains of its thickness

Cantor: You cook ukpatrök soup, he calls it "weakener of manhood"

Cantor: Pumpkin leaf is enough in the bush, my husband does not desire

Cantor: Bitter leaf in the bush, my husband does not desire.

Cantor: Ataama in the bush my husband does not desire.

Cantor: Every other edible leaf in the bush, my husband does not desire.

\section{Analysis}

This song is a traditional women's folk song. It satirizes or mocks a husband who is a loafer, but who is selective on the types of soup that he desires to eat; in this case, his only preference is afang soup, at all times. And from the tone of the song, it is indicated that the man cannot provide for the proper preparation of this soup he likes most. The satiric tone of the woman who brings this complaint is meant to ridicule her poor and lazy husband who is so selective of the kinds of soup he eats.

Fortuitously, afang is a delicacy among the Annang, Ibibio and their Efik brothers, and has fast become one the popular national dishes attracting connoiseurs from all over the world. Therefore, preparation of a pot of afang soup is a very expensive, not to talk of doing so on a daily basis. Any husband who refuses to adjust to the varieties of soup available in his environment is not realistic, hence the mockery in the women's voices. Through the song, the women showcase a menu of some of the kinds of soup available in the corpus of Annang cuisine: those mentioned here include but are not limited to okro, melon, ukpatrok, pumpkin leaf, bitter leaf, àtáàmà soups. The main aesthetic devices used by the women to demonstrate the man's dislike for other kinds of soups, are the use of repetitions, declaratives, and depreciation/devaluation or name-calling.

\section{The Use of Repetition}

Repetition is a major stylistic feature in most African songs. It is naturally built into the song and it is repetition that imbues this song with rhythm. The repetition involves repetition of specific lines as well as repetition of the entire song over and over again. This kind of repetition helps to stress or emphasize certain ideas the singer wishes to express. For instance, phrases like "chidém ádià áfàñ déé", "Ėbé ijémé” are repeated for emphasis.

\section{The Use of Assonance}

Assonance refers to the repetition of similar vowel sounds at regular intervals in a line of text or oral literature. There is assonance in "afo ábok", which is repeated all over the song text.

\section{The Use of Declarative}

The folksong makes use of declarative sentences as follows:

"Afo ábok ikpààn, anye'te mbad", "Afo abok atike, anye'te urod" etc. From the view point of function, declarative statements usually state facts, information or ideas. The ideas or facts may be of various levels of credibility (Eka 1990). 
Depreciation/devaluation or Name-calling

The man who is satirized in the text uses some form of devaluation technique to depreciate the value of other kinds of soup. For example:

\section{Original}

Cantor: Afo'bok atike, anye'te urod

Cantor: Afo'bok ikpaan anye'te mbaad

Cantor: Afo'bok úkpátrok anye’te úkpá éféd!

\section{Gloss}

You cook okro, he says "sliminess"

You cook melon, he says "thickness"

You cook úkpátrök, he says "manhood weakener!"

"Úkpátrok" referred to above, is a favourite local soup thickener among the people of the Cross River basin as well as the Igbo of the South-East. It is a seed that grows on a low bush, a plant that is indigenous to the areas where the thickener is a favourite food item. The words "sliminess", "thickness" and "manhood weakener" are depreciative words that force people to view the soup prepared using okro, melon or ukpatrok, in negative light.

\section{Song \#3}

Cantor: Nti Èwèp $(2 x)$

Cantor: Èwèp ákémán njàn itia-ita

Cantor: Kéd ábokko Ėwèp ákpá

Cantor: Èwèp átómmó Àwàsi ányoñ

Cantor: Éyén owəñ ádià nkpo kiwé

Cantor: Iliidiaoo kpàñ k'itəñ, kpà k'itıñ ajen Uko Nne

Cantor: Àkédiá seé?

Cantor: Nkédià ubó

Cantor: Úbó àkáánà

Cantor: Àkáánà àdé ábià

Cantor: Mméwá njómó, mméwá mmàn,

Cantor: Mméwá ámàn njén itiábà

Cantor: Ndiáñá kèd nno úkòd àmi

Cantor: Àkpéjém éwá kō̄̄ k’inyàñ

Cantor: Inyàñ kûm, kûm k'ùbóm

Cantor: Ủbóm kûm kûm k’inyàñ

Cantor: Nkániká itiáitá èsim énàñ ibà

Cantor: Ájén ádok àfé, èkà ádok èsàà...

\section{Gloss}

Cantor: I remembered Èwèp

Cantor: Ėwèp gave birth to eight children, and one of the children died

Cantor: Èwèp lamented to the Sky God

Cantor: A child that eats without salt

Cantor: Come and eat, glutton, as Uko Nne's son

Cantor: What did you eat?

Cantor: I ate úbó

Cantor: Úbó àkáánà

Cantor: Àkáánà is medicinal

Cantor: Dogs got pregnant and delivered

Cantor: The dogs delivered of eight puppies

Cantor: I gave one to my friend

Cantor: If you need one you get to the sea

Cantor: The sea hits kûm, kûm on the boat

Cantor: The boat hits kûm, kûm in the sea

Cantor: Two tails of a cow tails at eight o'clock

Cantor: The child enters the hall; the mother enters the backyard. 


\section{Analysis of Song 3}

This is a folk recitation that is popular with the Annang masses. The two main aesthetic devices apparent in the text above are repetition and ideophone.

\section{Repetition}

The entire text is an exercise in repetition. The first line of the text is repeated:

Nti Èwèp I remembered Ėwèp

Nti Èwèp I remembered Èwèp

The beauty of this folksong is portrayed as the following words are repeated: "kum" "kpàn k'itoñ" "Èwèp" "Mmêwa". Repetition is a poetic device that is always used to adorn works of arts. It promotes musicality.

\section{The Use of Alliteration}

As a sound device, alliteration contributes to the musicality and aesthetics of any orature. This unique device is employed in the folksongs by the user to beautify the work. Alliteration is identified in "kpàñ k'itoñ, kpañ k’itəñ", “enañ, inañ”, "kúm kùm k’ubóm” "mmèwá njómó” "mmèwá mmàn” etc.

The Use of Assonance

This refers to the repetition of similar vowel sounds at regular intervals. The following words are used for illustrating the use of assonance in the folksong: "àkánà àbiá ábià", "aboko àkpá”, "áyén ádûk ànén", "èkà áduk èsà"

\section{The Use of Ideophone}

This is a sound device that uses its sound to suggest its meaning. The phrase "kûm kûm" is self-explanatory; the sound suggests the pouring of water into the boat as well as the sound of sea water banging on the sides of the boat.

\section{Song \#4}

Cantor: Ibáán ilùñ ájid!

Chorus: Ànyéé, ànyényéé, ànyéé!

Cantor: Éjò ásièré

Cantor: Ègwo èjéém sé ènám,

Cantor: Kúsúk ùché èbé

Cantor: Ifiok ádè ùtip ùlii,

Cantor: Úbok kéd isióhó nnáñ

Cantor: Ifù idiáhá nnién

\section{Gloss}

Cantor: Women of our land

Chorus: Ànyéé, ànyényéé, ànyéé!

Cantor: It is dawn

Cantor: Go out and look for what to do

Cantor: Don't solely depend on your husband

Cantor: Knowledge is contributive

Cantor One finger does not remove lice

Cantor: A lazy man does not eat delicacies

\section{Analysis}

Song \# 4 is a didactic and satiric folksong performed by women in Annang dialect. The folksong persuades the women folk to rise up and assist their husbands. The song is therefore a reflection of the high premium the Annang society place on the need for the betterment of their families and the society. Aesthetically, the folksong is adorned with some aesthetic elements like repetition, assonance, rhythm etc.

The Use of Repetition: The chorus of the song which forms the musicality of the song is repeated severally.

\section{The Use of Assonance}

There is also repetition of a similar vowel in the lines below:

"Ibáán ilùng /i/

“Ègwっ èjéém /e/ 
"Ùtip ùlii /u/

"Ifù iliáhá /1/

\title{
The Use of Space-fillers
}

This song is antiphonal, and where the chorus do not have any appropriate response to checkmate the cantor, they resort to the use of space-fillers. A typical example is found in this song, in line 2 . When the cantor dresses the women thus: 'Women of our land!' The chorus respond with a space-filler: 'Chorus: Ànyéé, ànyényéé, ànyéé!'. These space fillers serve to enhance the rhythm and melody of the song.

Rhythm: There is a metrical movement in the song. The rising and falling pitches of the song which constitute the rhythm make the song musical, melodious and beautiful.

\author{
Song \#5 \\ Cantor: Èbé ku ntok àbà \\ Refrain: Tok àkàli \\ Cantor: Úkúdó àfoñ-isin? \\ Cantor: Àkpikım ùlándis \\ Cantor: Úkúdó àjioji? \\ Cantor: Úkúdó àwágsi? \\ Cantor: Úkúdó àfoñidém? \\ Cantor: Úkúdó àfəñiwuó? \\ Cantor: Úkúdó ikpáikód? \\ Cantor: Úkúdó ekpadúbok? \\ Cantor: Úkúdó nkwà itoñ? \\ Cantor: Úkúdó nkwà úbok? \\ Cantor: Úkúdó ibá éfúd? \\ Cantor: Úkúdó úlèbè ànyén? \\ Cantor: Úkúdó ifiıño álàn? \\ Cantor: Úkúdó àdàd inuá? \\ Cantor: Úkúdó àwoosi?
}

\section{Gloss}

Cantor: My husband, don't cheat me again*

Refrain: Grate garri

Cantor: Don't you see wrappers?

Cantor: Even hollandaise

Cantor: Don't you see George wrapper?

Cantor: Don't you see wax?

Cantor: Can't you see blouse?

Cantor: Don't you see head tie?

Cantor: Don't you see some pairs of shoes?

Cantor: Don't you see hand bag?

Cantor: Don't you see necklace?

Cantor: Don't you see bangles?

Cantor: Don't you see panties?

Cantor: Don't you see eye pencil?

Cantor: Don't you see body cream?

Cantor: Don't you see lipstick?

Cantor: Don't you see wrist watch?

\section{Analysis}

Song \#5 is a dramatic piece which showcases the reaction of a wife to her husband who has been oppressing and cheating her out of those accoutrements that a woman needs to make herself presentable to her husband and the public. She tells the husband not to cheat her, but should rather grate cassava to obtain (food) garri (fried cassava meal). In essence, the husband has failed in his responsibility and as such, the wife is not comfortable. Garri is a meal prepared from cassava, and it is the staple of the Akwa Ibom populace, which includes the Annang people. In order to ensure food sufficiency, people are expected to grate cassava into dough that would be later fried into garri. Therefore, the wife is telling the husband that rather than cheat or oppress her, he should help her to grate cassava to obtain garri so that they would have enough food to feed their family. 
From the aesthetic point of view, there is a careful use of some stylistic features to beautify the oral piece such as pun, rhythm, alliteration, rhetorical question, coinages/corrupt usages etc.

\section{The Use of the Rhetorical Question Device}

The main stylistic cum aesthetic device in the song is the use of the rhetorical question device. A rhetorical question, according to Holman (1960:416), is a

question propounded for its rhetorical effect and not requiring a reply or intended to induce a reply. The rhetorical question is most used in persuasion and in oratory, the principle supporting the use of the rhetorical question being that since its answer is obvious and usually the only one possible, a deeper impression will be made on the hearer by raising the question than by the speaker's making a direct statement.

The song under review effectively showcases elements of the rhetorical question in that the mistreated wifepersona asks her irresponsible husband series of questions as follows:

Cantor: Don't you see wrappers (loin-cloths)?

Cantor: Even hollandaise

Cantor: Don't you see George wrapper?

Cantor: Don't you see Wax?

Cantor: Can't you see blouse?

Cantor: Don't you see head-tie?

By these series of questions, the emphasis is made that the husband has failed in his duty of taking care of his wife's physical appearance, and therefore, is culpable for censure.

\section{The Use of Pun}

There is a play upon words when the wife says "Kú ntok àbà", (don’t cheat me again) "tok àkàli” (grate cassava for garri). In other words, cassava is meant for grating, and not human beings). The pun is biting in Annang in the word: "tok". The word "tok" in Annang, depending on context, can mean "cheat" or "be unjust", on the one hand, or "grate", in another context. Both meanings are implied in the song above, as follows:

Refrain: Tok àkàli Cantor: Èbé ku ntok àbà Husband, do not cheat me again

The pun above is intended to create fun, cause laughter and heighten the melodious effect of the song. The refrain of the song "Tok àkàli - Grate garri (i.e. to process cassava to obtain garri)" also reveals the women's disapproval of lazy, irresponsible husbands in their society/ communities.

\section{The Use of Coinage/Corupt usages}

There is a careful use of coinage in the folksong which showcases the user's creative prowess. These words are coined from English words or words of other languages foreign to Annang. Since the words cannot be properly pronounced by Annang uneducated women, they tend to substitute their own corrupt rendition of those words, which ultimately portray beauty in their use of language, e.g. "àkàli” (garri), "àjioji (George wrapper), and "àwoosi (wrist watch). The careful use of these stylistic elements portray the emphasis on aesthetics in Annang folksongs.

\section{The Use of Rhythm}

Rhythm refers to the alternation of stressed and unstressed syllables in the lines of the text or oral literature. These metrical patterns give rise to the movement or musicality of the oral performance. Song \# 5 is made up of some rising and falling tones which result in the movement that portrays the beauty of the folksong.

\section{Conclusion}

This paper has attempted to analyse a selection of Annang folksongs and recitations to bring out those aesthetic elements that qualify them to be classified as oral literature. This has been necessary in view of the fact that over the years, these songs have been used without thought as to their aesthetic qualities. Some of the stylistic and aesthetic features identified in the songs presented for analysis include the use of repetition, alliteration, assonance, rhetorical question, pun, rhythm, coinage, declarative statements, and onomatopoeia, among others. What this research has brought out is that Annang folksongs in their different levels would continue to entertain, educate, and inform the people, even in these days of modernity (Gunner 2007), and also form creative sub- 
forms that continue to be aesthetically rewarding, and therefore, form an authentic component of oral literature that deserves further scholarly attention.

\section{References}

Akpan, E. \& Etuk, U. (1990), Aesthetics: Philosophical and Artistic Dimensions. Uyo: Modern Bus. Press.

Angmor, C. (1993), "Two Decades of Contemporary Nigerian Novel", Journal of Humanities, Vol.III, September, University of Uyo, 111-123.

Connell, B. (1994), "The Lower Cross Languages: A Prolegomena to the Classification of the Cross River Languages". Journal of West African Languages, 24 (1), 3-6.

Eka, D. (1990), Elements of Grammar and Mechanics of the English Language. Uyo: Samuf.

Essien, O. E. (1990), A Grammar of Ibibio Language. Ibadan: University Press.

Essien, U. E. (1973), “Annang in the Polyglotta Africana”, David Dalby (Ed.), African Language Review, Vol. 9. London: Frank Cass. 177-183.

Finnegan, R. (1996), Oral Literature in Africa. Nairobi: Oxford University Press.

Greenberg, J. H. (1963), The Languages of Africa. The Hague: Mouton.

Gunner, L. (2007), “Africa and Orality”, African Literature: An Anthology of Criticism and Theory. Malden: Blackwell Publ. 67-73.

Holman, H. (1960), A Hand Book to Literature. New York: Odyssey, 1960.

Koelle, S.W. (1854), Polyglotta Africana. Republished online by Cambridge University Press, 2012.

Onuekwusi, J. (2001), Fundamentals of African Oral Literature. Owerri: Alphabet, 2001.

Udoh, E. U. (1983), The History of the Annang People: Cross River State, Nigeria. Calabar: Apcon Press.

Udoh, I. I. (1998), "The Effect of Duration on the Intonation of Annang Learners of English"; An Unpublished Ph.D Dissertation of the Department of Languages and Linguistics, University of Calabar.

Udondata J. (2011), Annang Traditional Literature. Uyo: Scholars Press.

Williamson, K. (1989), “Benue-Congo Overview”, Bendor-Samuel (Ed.) The Niger-Congo Languages. London: University Press. 247-274.

Friday A. Okon, PhD, is an Associate Professor in the Department of English, University of Uyo, Uyo, Nigeria. His area of specialization is African written and oral literature.

Inimfon D. Udoinyang is a Graduate Assistant in the Department of Curriculum Studies, Management and Planning of the University of Uyo, Uyo, Nigeria. 